\title{
Board Composition, Ownership Structure, Geographic Regulation, And Bank Holding Company Expenses
}

Eric Haye, Ramapo College of New Jersey, USA

\begin{abstract}
The purpose of this article is to explore the impact of internal and external market conditions on bank holding company operating expenses. An agency problem exists whenever management makes decisions which produce results contrary to shareholder interests. Factors such as large-block shareholdings, management participation in ownership, product and labor market competition, outsider board participation and ease of market entry are believed to serve as mitigating factors. Although there is evidence that product and ownership conditions have a significant effect operating expenses and other expenditures deemed to be preferred by management, there is scant evidence on the importance of these factors relative to board composition and entry barrier regulation. Furthermore, most of the focus has been on relatively large banking institutions. Employing a sample of small-to-medium banking firms from the 1980s, the results indicate that entry barrier regulation and board composition served as an important source of agency problems for these firms as reflected in the operating expense structure.
\end{abstract}

Keywords: Banking; Finance; Ownership Structure; Corporate Governance and Control

\section{INTRODUCTION}

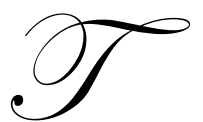

he impact of governance and control conditions on the performance and behavior of firms has been studied for some time. Some of this agency-theoretic research involves tests of the expensepreference hypothesis, which purports that certain internal and external control conditions, such as diffusely-held shares, insufficient outsider board participation, non-competitive markets, and the reduced threat of takeover, to name a few, hamper the decision-control process between shareholders and managers by providing incentives which ultimately lead to the attenuation of owner control over firm expenses.

High diffusion of voting shares increases the cost to owners of effectively supervising and scrutinizing executive decision-making. Heightened executive board participation and the attainment of key board positions by executives encumbers outside directors in their attempt to devise and implement share-price maximizing policies. Non-competitive effects stemming from concentrated product markets or regulatory entry barriers enhance free cash flow for all firms in the market and, presumably, executive discretion over cash flow. Assuming that the market for managerial talent is competitive and fully-functioning ${ }^{1}$, one would expect higher managerially-preferred expenses from firms subject to each or any of these conditions relative to their presumably more disciplined counterparts.

This paper examines the relative impact of ownership structure, board composition, government regulation and product market structure on bank operating expenses during the Glass-Steagall era. Employing a nationwide sample of small-to-medium sized bank-holding companies, the results indicate that agency effects are not evenly distributed across the structure of expenses and that board composition and geographic branching restrictions, neglected factors in much of the prior research, play an important role relative to ownership and product market

${ }^{1}$ Fama (1980) contends that a fully functioning internal and external market for managerial labor should provide sufficient discipline to extinguish the agency premium embedded in expenses. However, circumstances such as asymmetric information or the inability to evaluate the productivity of individual managers may leave the ex post settling up process incomplete. 
structure in the determination of bank expenses. The next section is a brief overview of the empirical research on agency effects and bank expenses.

\section{LITERATURE REVIEW}

Although there is evidence suggesting that ownership structure and product market concentration meaningfully influence bank input utilization and operating expenses, there are a number of studies which contest this. In addition, there has been relatively little research on the impact of executive board participation on bank expense-taking. ${ }^{2}$ Employing deposit market concentration to proxy non-competitive effects, Edwards (1977), using aggregate banking market data, and Hannan (1979) using individual bank data, found higher bank employment and personnel expenses in non-competitive markets. There have subsequently been studies identifying non-competitive effects on non-personnel expenses as well (Hannan and Mavinga (1980), Glassman and Rhoades (1980), James (1984) and Rose (1992)). Hannan and Mavinga (1980) find that share diffusion produces lower personnel and nonpersonnel expenses, while Glassman and Rhoades (1979) obtain this result for non-personnel expenses only. Brickley and James (1987) find that salary expenditures are lower for banks in non-acquisition states with either high outside board participation or concentrated share holdings. Pi and Timme (1992) find lower cost efficiency for banks in which the CEO is the Chairman of the Board and that efficiency is positively related to CEO ownership for Nonchairman-CEO banks; however, they find no agency effects for either large-block ownership concentration or insider board representation. Berger and Hannan (1998) find that concentrated shareholdings and competitive markets promote bank cost efficiency. Akella and Greenbaum (1988) find evidence of expense-preference behavior in the savings and loan associations during 1979-1980; Gropper and Hudson (2003) corroborate this finding for the same time period and also find diminished expense-preference behavior and increased managerial efficiency during the succeeding period of deregulation and heightened competition. However, there are also a number of studies which find little or no evidence of non-competitive effects. Glassman and Rhoades (1980) and Rose (1992) find that banks in more concentrated product markets do not have higher personnel expenses. Smirlock and Marshall (1983) assert that differences in bank input utilization are better explained by organizational complexity rather than product market structure. Other studies in this vein include Rhoades (1980) and Scott, Gardner and Mills (1988). In general, the evidence on the relative importance of non-competitive, ownership, board and entry barrier effects throughout the structure of bank operating expenses is mixed and scant. ${ }^{3}$

\section{METHODOLOGY}

The following model accounts for those factors which may influence the decision-control process and, as a result, the level of bank operating expenses, or those expenditures deemed to be preferred by executives. Assuming imperfections in the market for managerial services, or that the market for those services is fully-functioning and frictionless but insufficient to completely extinguish agency effects, expenses are a function of i) firm size ii) output heterogeneity iii) the cost of labor, capital, land and premises iv) non-price factors effecting final product demand v) product market concentration vi) regulatory entry barriers vii) ownership structure and vii) board composition.

The size of the banking organization is probably the most important factor in determining expenses. Larger banking organizations have a greater volume of transactions to conduct, requiring greater utilization of inputs. In addition, these organizations are often characterized by layered decision-making with complicated operating strategies, making it particularly difficult for shareholders to supervise and control. So, from a volume of transactions perspective as well as a governance perspective, larger firms should generate higher expenses.

Banking firms have differences in asset and liability composition, production technologies and risk which can affect the expense structure. Increases in the cost of production factors such as labor and land will prompt firms to reduce output and expenses. Banks operating in markets characterized by a high demand for bank products and

\footnotetext{
${ }^{2}$ The focus here is on institutions primarily involved in commercial banking. For evidence on the savings and loan industry see Verbrugge and Jahera (1981), Simpson and Kohers (1980) and Blair and Placone (1988). For evidence of expense-preference behavior for non-financials see Awx and Primeaux (1985).

${ }^{3}$ For instance, Glassman and Rhoades (1980) and Rose (1994) find that non-competitive effects are more prominent for nonpersonnel expenses, such as premises and equipment expenses and miscellaneous expenses. Rose (1994) identifies a negative coefficient on deposit concentration in his non-personnel expense equation, a result which is at odds with Edwards (1977).
} 
services should have higher expenses.

The impact of product market structure on the demand for inputs and expenses and reflects both derived demand and organizational control considerations. Reduced market competition and the consequent impact on final demand elasticity should lead to a reduction in industry output. If market shares remain constant, the derived demand for labor for each firm will fall as well. However, non-competitive effects may enable firms to increase input utilization and expenses beyond what is called for by the derived demand schedule. If agency effects are present in non-competitive markets, and if the intensity to engage in agency-theoretic behavior is identical across banks (holding the bank's ownership and board structure constant), then one would expect to observe higher expenses in concentrated product markets.

Agency effects may also be present in markets protected from the threat of entry or expansion by government regulation. Rules prohibiting branching or interstate banking may stifle market competition, since they reduce the number of banks with access to the market and, thereby, the threat of entry and expansion to all participants. This assumes that regulatory authorities do not compensate by expanding the number of banking firms in the market. However, entry and expansion regulations may also drive market participants to adopt production technologies best suited to the regulatory policy in effect.

The ownership structure of the bank refers to both the concentration of share ownership and the degree of executive participation in ownership. According to agency theory, firms with more concentrated share holdings maintain lower expenses, since their owners have a greater incentive to monitor corporate behavior and face a lower cost in enforcing share price maximizing policies. Furthermore, the incentive of executives to limit expenses increases the higher their proportionate share holdings relative to other investors and relative to the their own total wealth. Evidence of agency-theoretic behavior exists if more concentrated share holdings or greater executive stock participation is associated with lower expenses. We would accept the null hypothesis and reject the presence of agency-theoretic effects if no relationship can be identified between principal or executive ownership and bank input utilization and expenses.

Although there is evidence that outsider representation on the board of directors has been increasing, very few regulations mandating board size, composition or committee structure and function exist ${ }^{4}$. Insiders possess important specific information and expertise regarding corporate activities and operations; their direct involvement should facilitate the planning process and lead to more efficient corporate behavior. ${ }^{5}$ However, this "expertise effect" does not completely account for the motivations of insiders. Insiders could use their heightened influence over strategic decision-making to indulge their proclivities for higher expenses. ${ }^{6}$ So whether expertise or agency effects dominate is an issue that can only be resolved empirically.

\section{EMPIRICAL MODEL}

Assuming that the cost of capital and the rental price of premises are constant across banking markets, the model below is based on the theoretical discussion in the methodology section and is used in the regression estimations which follow:

(1) $\quad$ EXP $=\mathrm{f}($ Total deposits, Bank offices, Net loans-to-securities, Per capita income, Wage rate, Deposit concentration, Limited branching restrictions, Statewide branching, Interstate activity restrictions, Principal ownership, CEO ownership, Board insider participation, Board Chair is the CEO)

in which EXP refers to the three operating expenses of the holding company under observation, total salaries and benefits (SAL), furniture and equipment expenses (FEE) and net occupancy expenses and $\ln$ refers to the natural log.

\footnotetext{
${ }^{4}$ see Baysinger and Butler (1985), Brickley and James (1987) and John and Senbet (1998).

${ }^{5}$ see Fama and Jensen (1983).

${ }^{6}$ Hermalin and Weisbach (1988) find that outsiders are more likely to join boards and insiders more likely to exit after a firm performs poorly, suggesting the presence of agency effects.
} 
It is assumed that if expense-preference and agency effects are present that they are likely to appear in the operating expense structure. However, it is unlikely that these effects are equally distributed across expenses. The greater the scrutiny that an expense undergoes by the investing public or the more accountable management is for a particular expense, the lower the likelihood that management will use that expense as a vehicle for agency-theoretic behavior. It is asserted here that personnel expenses, such as salaries and benefits, are held to greater public scrutiny and that executives are more accountable for excesses in these expenses as opposed to non-personnel expenses, such as office furnishings or occupancy expenses. However, if managers derive more utility from personnel expenses as opposed to non-personnel expenses, then their incentive to indulge in personnel expenses is greater. Since there is no way of determining a priori which category of bank expenses is more subject to agency-theoretic behavior, each is entered into separate estimations.

Total deposits measure the size of the banking firm. The number of banking offices and the net loans-toinvestment securities ratio for the banking firm are entered to capture output heterogeneity effects regarding capital investment and portfolio composition. Larger banking organizations with more offices are expected to conduct a greater number of transactions and operating activities. The net loans-to-securities ratio is included to correct for output differences between banking firms. Since lending is assumed to be a relatively risky activity requiring greater investment of labor, equipment and space, one would expect banks that have a relatively larger fraction of their assets in loans as opposed to securities to maintain higher operating expenses.

The per-capita income of the banking market is intended to capture demand-side effects on bank output. The banking market is defined as the Metropolitan Statistical Area (MSA) or county if there is no MSA in which the banking firm derives its largest proportion of deposits. Markets which have higher per-capita income are more prosperous and demand more banking transactions and services; therefore, banks operating in these markets are expected to generate higher expenses.

Wage rate refers to the manufacturing wage rate for that state in which the banking firm is headquartered and proxies the market cost of labor. Manufacturing wage rates are used since rates based on banking or financial services employees may be contaminated by agency-theoretic behavior. Higher wage rates should encourage banks to reduce input usage.

Deposit concentration is designed to measure the degree of product market competition while limited branching restrictions, statewide branching regulations and interstate activity restrictions account for the impact of geographic branching and expansion limitations on bank expense-taking. Deposit concentration is measured by the continuous three-firm bank deposit concentration ratio in that market from which the bank holding company maintains its greatest deposit presence. Geographic branching and expansion regulations are represented by dummy variables, with limited branching $=1$ if the banking firm is headquartered in a limited branching state, statewide branching $=1$ if in a statewide branching state and the no interstate activity dummy $=1$ if the banking firm is located in a state prohibiting interstate banking activity, 0 otherwise.

If managerial-entrenchment effects are present, banks located in concentrated deposit markets should have higher expenses. Banks located in states without entry and access restrictions, such as limited or statewide branching states and states which maintain interstate banking laws, should have lower expenses than their more protected counterparts.

Principal ownership is the percentage of stock beneficially held by the largest principal shareholder and CEO ownership is the percentage of stock owned by the CEO. If agency effects transmitted through share diffusion and executive ownership are present, both should be negatively related to expenses.

Finally, two board composition variables are entered into the estimations - insider participation, or the percentage of current or former executives of the bank holding company on the board of directors and $\mathrm{CBD}=\mathrm{CEO}$, a binary variable $=1$ if the $\mathrm{CEO}$ also serves as the Chairman of the Board, 0 otherwise. If insider participation works to create more informative and decisive boards, then negative signs on these variables are expected. However, if insiders serve to encumber the ability of board outsiders to supervise and discipline corporate behavior, then positive sign coefficients are expected. If sign coefficients on all the agency-theoretic variables are not significantly different 
from 0 , we would then reject the alternative hypothesis and accept the null hypothesis that ownership and board structure have no meaningful expense-preference ramifications.

\section{SAMPLE AND DATA}

The sample consists of 127 bank holding companies in 1986. These firms were drawn from a randomlyselected larger pool of 222 bank-holding companies in which the lead bank is state-chartered and a member of the Federal Reserve System. Banking firms were rejected from the initial pool if insufficient data was obtained.

Definitions of dependent and explanatory variables appear on table 1, and sample means and standard deviations appear on table 2. The average sample holding company has total consolidated assets of $\$ 484$ million, with a range of $\$ 2.654$ billion to $\$ 19.94$ million. The sample is dominated by smaller banking firms, with 86 firms (67.7\%) having total assets less than $\$ 500$ million and with 43 (33.9\%) maintaining total assets of less than $\$ 150$ million. Alternatively, 20 firms $(15.7 \%)$ have total assets greater than $\$ 1$ billion.

Although the 41 banking firms with more than $\$ 500$ million in total assets maintain a lower ratio of net loans-to-investment securities (3.46 versus 7.70 ), the two sets of firms have relatively equivalent largest principal ownership shares (10.74\% versus $10.85 \%$ ) and deposit concentration ratios (58.5\% for the 41 largest versus $60.8 \%)$. Insiders are more likely to serve on the board for the larger holding companies (24.9\% versus $19.7 \%)$ and the CEO is more likely to be Chairman of the Board (48.8\% versus $27.9 \%$ ). Approximately $26 \%$ of the banking firms are headquartered in limited branching states while the bulk of the sample $(62 \%)$ is headquartered in states with no geographic branching limitations. ${ }^{7}$

\section{RESULTS}

All regression estimates regarding total salaries and benefits (SAL), furniture and equipment expenses (FEE) and net occupancy expenses (OCC) appear in table 3. With the exception of the binary variables (limited branching, statewide branching, no interstate activity and Board chair=CEO) all other variables are entered into the regressions in natural $\operatorname{logs}(\ln )$. The $\mathrm{R}^{2} \mathrm{~s}$ for all three equations range from

$85 \%$ for SAL to $76 \%$ for OCC and FEE, indicating that the model accounts for a sizeable portion of the variation.

Regarding the agency-theoretic variables, board structure has a greater impact on expenses than either ownership or product market structure. Insider board participation posted positive and highly significant coefficients in all three estimations. The size of the coefficient in FEE and OCC reveals that insiders have greater influence over those expenses rather than SAL. In addition, CEO-Chairman firms generate higher expenses in all categories relative to CEO-Non-chairman firms; however, the effect is statistically significant only in the SAL equation.

The percentage of large-block share holdings and CEO ownership produced the expected negative sign but failed to be statistically significant. However, these effects may be present amongst only the larger banks in the sample. To capture this, Principal Ownership INT and CEO Ownership INT are interactive variables entered into the estimations accounting for shareholder control effects. Principal Ownership Int is equal to principal ownership*INT, in which INT is a dummy variable $=1$ if the banking firm's total consolidated assets are greater than $\$ 500$ million, 0 otherwise. The CEO interactive variable is constructed in an identical fashion. This ownership specification provides negative and statistically significant results on the principal ownership variable but the CEO ownership variable, indicating that more concentrated principal share holdings tend to reduce expenses. However, this effect is only observed for the larger banking firms, but the size of the parameter is relatively small.

\footnotetext{
${ }^{7}$ Data on expenses, total deposits, net loans and investment securities is obtained from the firm's annual report. The data used to construct the deposit concentration ratios as well as the number of branch banking offices and state branching status is

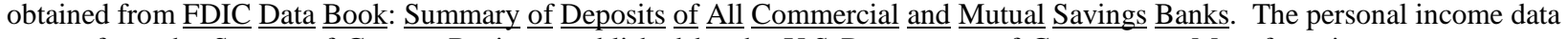
comes from the Survey of Current Business published by the U.S Department of Commerce. Manufacturing wage rates are obtained from Employment and Earnings published by the U.S. Department of Labor. All ownership and board structure data is obtained from proxy statements.
} 
Table 1

Variable Definitions

Dependent Variables

Total salaries and benefits of the banking firm (SAL).

Furniture and equipment expenses of the banking firm (FNE).

Net occupancy expenses of the banking firm (OCC).

\section{Explanatory Variables}

Total deposits, the total consolidated deposits of the banking company.

Number of banking offices of the banking company.

Net loans-to-securities ratio of the banking company.

Per-capita income of the banking market.

Wage rate, or the hourly manufacturing wage rate in the state in which the holding company is headquartered.

Deposit concentration equals the three-bank deposit concentration ratio for the banking market.

Limited branching status binary variable, equal to 1 if the banking company is headquartered in a statewide banking state, 0 otherwise.

State branching status binary variable, equal to 1 if the banking company is in a statewide banking state, 0 otherwise.

No Interstate activity binary variable, equal to 1 if the bank is located in a state which prohibits interstate banking activity (i.e., no nationwide or reciprocal banking arrangements), 0 otherwise.

Principal ownership refers to the percentage of stock beneficially held by the largest large-block shareholder of the holding company.

CEO Ownership refers to percentage of stock held by the CEO of the holding company.

Insider participation, or the percentage of insiders on the board of directors, is equal to the number of current or former banking company executives serving on the board of directors of the holding company divided by total board membership.

Board Chair=CEO binary variable is equal to 1 if the Chairman of the board of the holding company also serves as CEO or President, 0 otherwise.

Table 2

Descriptive Statistics ${ }^{8}$

\begin{tabular}{lll}
\hline Variable & Mean & $\begin{array}{l}\text { Standard } \\
\text { Deviation }\end{array}$ \\
\hline Total Salaries and Benefits (SAL) & $\$ 7,845,013$ & $\$ 8,795,746$ \\
Furniture and Equipment Expenses (FEE) & $\$ 2,084,918$ & $\$ 5,662,776$ \\
Net Occupancy Expenses (OCC) & $\$ 1,484,875$ & $\$ 9,835,000$ \\
Total Assets & $\$ 483,558,107$ & $\$ 560,352,163$ \\
Total Deposits & $\$ 413,254,902$ & $\$ 467,831,631$ \\
Banking Offices & 13.07 & 14.87 \\
Net loans-to-investment securities & 6.34 & 10.51 \\
Per-capita income & $\$ 15,220$ & $\$ 3,611$ \\
Deposit Market Concentration & $60.03 \%$ & $18.36 \%$ \\
Limited Branching & $25.98 \%$ & $44.03 \%$ \\
Statewide Branching & $62.20 \%$ & $48.68 \%$ \\
No interstate banking activity & $11.02 \%$ & $31.44 \%$ \\
Principal Ownership & $10.81 \%$ & $12.32 \%$ \\
CEO Ownership & $3.96 \%$ & $7.20 \%$ \\
Insider Board Participation & $21.40 \%$ & $16.23 \%$ \\
CEO is Chair of the Board (Board Chair=CEO) & $34.65 \%$ & $47.77 \%$ \\
\hline
\end{tabular}

The deposit concentration ratio generated the expected positive sign in all estimations, but was significant only in the FEE equation. The limited and statewide branching status dummies produced negative and highly significant results; however, the results were not monotonic with respect to branching status, which is similar to what was obtained in Berger and Mester (1997). Although banks in both limited and statewide branching states maintain lower operating expenses than banks in unit banking states, banks in limited banking states had lower costs than those in statewide branching states, an unanticipated result but on which was also obtained by Berger and Mester (1997). Interstate banking restrictions do not have significant effects on bank expenses.

\footnotetext{
${ }^{8}$ All figures refer to 1986 and to the full 127 observation sample, with the exception of FEE (101) and OCC (117).
} 
Table 3

Regression Results ${ }^{9}$

Determinants of Bank Holding Company Expenses

\begin{tabular}{|c|c|c|c|}
\hline & Ln SAL & Ln FEE & Ln OCC \\
\hline Constant & $\begin{array}{l}2.987 \\
(1.60)\end{array}$ & $\begin{array}{l}2.539 \\
(0.644)\end{array}$ & $\begin{array}{l}-0.560 \\
(0.218)\end{array}$ \\
\hline Ln(Total Deposits) & $\begin{array}{l}0.357^{* * * *} \\
(7.16)\end{array}$ & $\begin{array}{l}0.329^{* * * *} \\
(4.43)\end{array}$ & $\begin{array}{l}0.393^{* * * *} \\
(5.81)\end{array}$ \\
\hline Ln(Bank Offices) & $\begin{array}{l}0.520^{\text {**** }} \\
(9.53)\end{array}$ & $\begin{array}{l}0.641^{* * * *} \\
(7.39)\end{array}$ & $\begin{array}{l}0.428^{* * *} \\
(5.70)\end{array}$ \\
\hline Ln (Net Loans-to- & 0.048 & 0.057 & $0.153^{* * *}$ \\
\hline Securities) & $(1.07)$ & $(0.79)$ & $(2.51)$ \\
\hline Ln(Per Capita & $0.449^{* * *}$ & 0.292 & $0.451^{*}$ \\
\hline Income) & $(2.57)$ & $(0.705)$ & $(1.88)$ \\
\hline Ln(Wage Rate) & $\begin{array}{l}0.396 \\
(1.02)\end{array}$ & $\begin{array}{l}0.797 \\
(1.28)\end{array}$ & $\begin{array}{l}0.921^{*} \\
(1.68)\end{array}$ \\
\hline Ln(Deposit & 0.195 & $0.577^{* *}$ & 0.200 \\
\hline Concentration) & $(1.27)$ & $(2.21)$ & $(0.96)$ \\
\hline Limited & $-0.659^{* * *}$ & $-0.745^{* * *}$ & $-0.717^{* * *}$ \\
\hline Branching Binary & $(4.37)$ & $(3.12)$ & $(3.39)$ \\
\hline Statewide & $-0.543^{* * *}$ & -0.435 & $-0.441^{* *}$ \\
\hline Branching Binary & $(4.14)$ & $(2.06)$ & $(2.42)$ \\
\hline No Interstate & 0.055 & -0.038 & 0.290 \\
\hline Activity Binary & $(0.42)$ & $(0.16)$ & $(1.56)$ \\
\hline Ln(Principal & $-0.017^{* *}$ & $-0.030^{* *}$ & $-0.031^{* * *}$ \\
\hline Ownership Int) & $(2.06)$ & $(2.32)$ & $(2.81)$ \\
\hline $\operatorname{Ln}(\mathrm{CEO}$ & 0.013 & 0.011 & 0.050 \\
\hline Ownership Int) & $(0.28)$ & $(0.16)$ & $(0.82)$ \\
\hline Ln(Insider & $0.178^{* * *}$ & $0.302^{* * *}$ & $0.217^{* * *}$ \\
\hline Participation) & $(2.53)$ & $(2.77)$ & $(2.20)$ \\
\hline Board Chair-CEO & $0.185^{* * *}$ & 0.029 & 0.099 \\
\hline Binary & $(2.19)$ & $(0.197)$ & $(0.82)$ \\
\hline Adjusted $\mathrm{R}^{2}$ & 0.852 & 0.757 & 0.755 \\
\hline F-statistic & 56.77 & 24.95 & 28.54 \\
\hline $\mathrm{N}$ & 127 & 101 & 117 \\
\hline
\end{tabular}

Regarding the remaining variables, both total deposits and banking offices provide the most powerful impact on expenses, with estimated coefficients in keeping with prior research. Per-capita income has the expected positive effect on SAL and OCC, but is insignificant in the FEE equation. The ratio of net loans-to-investment securities has a positive and significant effect on occupancy expenses but not labor expenses or furniture and equipment expenses. The market wage rate provides statistically significant results only in the OCC equation, but an unexpected sign coefficient.

\section{CONCLUSION}

This paper analyzes the impact of imperfections in the market for corporate control on the management of bank holding company expenses. Using a sample of small-to-medium sized banking firms, the evidence indicates that board composition and state branching restrictions played a more important role for these institutions than product market or ownership structure. The evidence failed to support the hypothesis that product market concentration has a meaningful influence throughout the structure of operating expenses and finds evidence of a large-block ownership effect, but only for the larger firms. Finally, these agency effects were not evenly distributed

\footnotetext{
${ }^{9}$ t-statistic in parentheses. $\mathrm{SAL}=$ total salaries and benefits; FEE $=$ furniture and equipment expenses and OCC $=$ net occupancy expenses. All F-stats are statistically significant at the $1 \%$ level. Ln refers to the natural log of the variable. $\mathrm{N}$ refers to the number of observations. All data is from 1986. $* * *=$ significant at the $1 \%$ level. $* *=$ significant at the $5 \%$ level. $*=$ significant at the $10 \%$ level.
} 
across operating expenses, with non-personnel expenses more influenced than personnel expenses.

\section{AUTHOR INFORMATION}

Dr. Eric Haye is an Associate Professor of Finance at Ramapo College of New Jersey and a Research Associate at Binghamton University. He has published numerous articles and has presented papers at professional meetings. His research is in the areas of Corporate Governance and Control, International Finance, Capital Structure, Executive Compensation and Bank Management and Performance.

\section{REFERENCES}

1. Akella, Srinivas R. and Stuart I Greenbaum, 1998. "Savings and Loan Ownership Structure and ExpensePreference" Journal of Banking and Finance 12, 419-437.

2. Awh, Robert Y. and Walter J. Primeaux, Jr., 1985. "Managerial Discretion and Expense Preference Behavior" Review of Economics and Statistics 67, 224-231.

3. Baysinger, Barry D. and Henry N. Butler, 1985. "Corporate Governance and the Board of Directors: Performance Effects of Changes in Board Composition" Journal of Law, Economics, and Organization 1, 101-124.

4. Berger, Allen N. and Timothy H. Hannan, 1998. "The Efficiency Cost of Market Power in the Banking Industry: A Test of the 'Quiet Life' and Related Hypotheses" Review of Economics and Statistics 80, 454-465.

5. Berger, Allen N. and Loretta J. Mester, 1997. "Inside the black box: What explains differences in the efficiencies of financial institutions?" Journal of Banking and Finance 21, 895-947.

6. Blair, D. and D. Placone, 1988. "Expense-Preference Behavior, Agency Costs and Firm Organization: The Savings and Loan Industry" Journal of Business and Economics 40, 1-15.

7. Brickley, J.A. and C.M. James, 1987. "The Takeover Market, Corporate Board Composition and Ownership Structure: The Case of Banking" Journal of Law and Economics 30, 161-180.

8. Edwards, F.R., 1977. "Managerial Objectives in Regulated Industries: Expense Preference in Banking" Journal of Political Economy 85, 147-162.

9. $\quad$ Fama, Eugene F., 1980. "Agency Problems and Residual Claims" Journal of Political Economy 88, 288307.

10. Fama, Eugene F. and Michael C. Jensen, 1983. "Separation of Ownership and Control" Journal of Law and Economics 26, 301-325.

11. Glassman, C. and S. Rhoades, 1980. "Owner vs. Manager Control Effects on Bank Performance" Review of Economics and Statistics 62, 263-270.

12. Gropper, Daniel M. and Carl D. Hudson. 2003. "A Note on Savings and Loan Ownership Structure and Expense Preference: A Reexamination” Journal of Banking and Finance 27, 2003-14.

13. Hermalin, Benjamin E. and Michael S. Weisbach, 1988. "The Determinants of Board Composition" Rand Journal of Economics 19, 589-606.

14. Hannan, T., 1979. "Expense-Preference Behavior in Banking: A Reexamination" Journal of Political Economy 87, 891-895.

15. Hannan, T. and F. Mavinga, 1980. "Expense Preference and Managerial Control: The Case of the Banking Firm" Bell Journal of Economics 11, 671-682.

16. James, Christopher, 1984. "An Analysis of the Effect of State Acquisition Laws on Managerial Efficiency: The Case of the Bank Holding Company Acquisitions" Journal of Law and Economics 27, 211-226.

17. Jensen, Michael C. and William H. Meckling, 1976. "Theory of the Firm: Managerial Behavior, Agency Costs and Ownership Structure" Journal of Financial Economics 3, 305-360.

18. John, Kose and Lemma W. Senbet, 1998. "Corporate Governance and Board Effectiveness" Journal of Banking and Finance 22, 371-403.

19. Keating, Barry P. and Maryann O. Keating, 1992. "An Empirical Estimation of the Degree of Expense Preference Behavior between Credit Unions by Common Type" Quarterly Review of Economics and Finance 32, 71-84.

20. Pi, Lynn and Stephen G. Timme, 1993. "Corporate Control and Bank Efficiency" Journal of Banking and Finance 17, 515-30. 
21. Rhoades, S., 1980. "Monopoly and Expense Preference Behavior: An Empirical Investigation of a Behavioralist Hypothesis" Southern Economic Journal 16, 419-432.

22. Rose, Peter S., 1992. "Agency Theory and Entry Barriers in Banking" Financial Review 27, 323-353.

23. Rosenstein, Stuart and Jeffrey G. Wyatt, 1990. "Outside Directors, Board Independence, and Shareholder Wealth" Journal of Financial Economics 26, 175-191.

24. Scott, William L., Mona J. Gardner and Dixie L. Mills, 1988. "Expense Preference and Minority Banking: A Note" Financial Review 23, 105-115.

25. Smirlock, M. and W. Marshall, 1983. "Monopoly Power and Expense Preference Behavior: Theory and Evidence to the Contrary" Bell Journal of Economics 14, 166-178.

26. Verbrugge, J.A. and J.S. Jahera, 1981. "Expense-Preference Behavior in the Savings and Loan Industry" Journal of Money, Credit, and Banking 13, 469-476. 


\section{NOTES}

